\title{
STUDY ON THE ECOLOGICAL EFFICIENCY AND ITS TEMPORAL DYNAMIC EVOLUTION OF CHINA'S CRUISE TOURISM FROM THE PERSPECTIVE OF CARBON FOOTPRINT
}

\author{
YE, X.L. ${ }^{1}-$ WANG, L. $^{1}-$ ZHU, Z.F. ${ }^{2}-$ DU, J. ${ }^{2}-$ SUN, R.H. ${ }^{1 *}$ \\ ${ }^{I}$ Department of Business Administration, School of Management, Shanghai University of \\ Engineering Science, 333 Longteng Road, Songjiang District, Shanghai, China \\ (e-mail: yexinliang@sues.edu.cn; phone/fax: +86-21-6787-4142) \\ ${ }^{2}$ Jiuzhai Valley Scenic Area Administration, Zhangzha Town, Jiuzhaigou County, Aba Tibetan \\ and Qiang Autonomous Prefecture, Sichuan Province, China \\ (e-mail: 183796414@qq.com; ecojay@163.com; phonelfax: +86-83-7773-9753) \\ *Corresponding author \\ e-mail: sunruihong@sues.edu.cn \\ (Received 22 $2^{\text {nd }}$ May 2019; accepted 28 ${ }^{\text {th }}$ Aug 2019)
}

\begin{abstract}
China has grown rapidly to be Asian maximum cruise economic market (Green Book of Cruise Industry, 2018). To facilitate cruise economic growth and harmonious coexistence with ecological environment, this paper proposes a new perspective of the ecological efficiency and computes carbon footprint of the cruise tourism in China from 2009 to 2017. The results show a relatively low level of ecological efficiency in nearly nine years, the average ecological efficiency of cruise tourism is CNY $67.99 / \mathrm{kg}$. In these nine years, ecological efficiency of cruise tourism within four years from 2011 to 2012 and from 2016 to 2017 is lower than the average and ecological efficiency within two years from 2009 to 2010 and from 2013 to 2015 is higher than the average, ecological efficiency within four years from 2013 to 2015 and 2017 is close to the average. Ecological efficiency has dropped continuously in 2011, but the overall carbon emissions and related carbon footprint of cruise tourism show the trend of rapid growth. It is necessary to explore a new way to develop cruise tourism, change the development mode of cruise tourism, rebuild a balance between industry booming and ecosystem by reducing resource consumption and pollution discharge, and further enhance ecological efficiency of cruise tourism.
\end{abstract}

Keywords: cruise travel, ecological efficiency, carbon footprints, temporal evolution, China

\section{Introduction}

As one of the fastest growing aspects of tourism, cruise tourism has become an industry power which cannot be ignored in driving the development of cruise ports and surrounding areas. Cruise tourism refers to trans-regional and transnational tourism activities, propelling industries relevant to ports with expansion of the cruise product market, logistics of cruise supplies, or even repair and maintenance of cruise ships. Cruise tourists and related spending can balance regional economic differences, even international balance of payments, and promote the prosperity of the local market. In 2006, international cruise lines began to enter Chinese market and start home port operation in China. It strongly boosts China cruise tourism market and constantly increases acceptance and engagement of tourists towards cruise tourism. China has become the largest Asian cruise tourist market and one of the fastest-growing cruise areas in the world. CCYIA's data shows 11 Chinese cruise terminals, including Shanghai and Tianjin, received totally 1,181 cruise ships in 2017, suggesting a year-onyear growth of $17 \%$. In terms of cruise visitor reception, China received totally 4.954 million inbound and outbound tourists at 11 cruise terminals, suggesting a year- 
on-year growth of 18\%. China's cruise revenue in 2017 is CNY (Chinese Yuan) 8.92 billion, which is increased by $32.5 \%$. As domestic coastal port cities have speeded up the development and investment on cruise industry, cruise development and construction and tourism activities will inevitably bring plenty of ecological and environmental challenges and problems, including coastal landscapes changes, loss of original ecological habitats, air pollution and environmental congestion when cruise ships are reaching and berthing at ports. Hence, how to reduce impacts of cruise ships on the ecological environment and realize sustainable development of cruise industry has become a high-profile issue in the industry and academic world. In this context, in order to protect ecological environment and achieve sustainable development of economy, this paper chooses the green and sustainable development of cruise economy as the aim and introduces the ecological efficiency index to evaluate the sustainable development status of cruise tourism by comparing ecological environmental loads with economic benefits, to explore a green development path for China cruise tourism, to propel the transformation and upgrading of the cruise tourism industrial structure and mode suitable for the marine ecosystem, and to improve ecological efficiency of cruise tourism.

\section{Literature review}

Despite considerable economic income brought by cruise development (Vina and Ford, 1999), the practical effect is affected by local economic development level and degree of integration in the global industrial chain, and thus cruise tourism's positive effect on local areas will be limited by local industrial structure, variety of products and reception capacity (Chase and Mckee, 2003; Chang et al., 2016; Sun and Hou, 2017). The areas where cruise ships pass through will be effected and suffer negative ecological impacts due to a great deal of waste coming from fuel consumption, energy use, food consumption, etc., which increases the ecological cost of local cruise tourism development and results in potential loss of cruise economic benefits (Chase and Mckee, 2003).

Scholar Erize (1987) showed concern over cruise ecological problems as early as 1980s, and Ritter and Schafer (1998) proposed that importance must be attached to marine pollution control with the rapid development of cruise tourism (Ritter and Schafer, 1998). On a basis of the life cycle theory, Johnson (2002) believes ecological problems and environmental pollution of cruise tourism is mainly caused by resource consumption and utilization, discharge of waste, infrastructure construction, passenger transport and logistics distribution (Johnson, 2002). In his point of view, cruise waste's impacts on environment include poor water quality (Lincoln et al., 2006), sea area pollution (Gibson et al., 2012), damage to coral reefs (Jones, 2007, 2011) and so forth. Along with global changes and climate warming in recent years, low-carbon emission reduction in cruise industry becomes a hot research topic. More empirical researches have been done on the sustainable development of cruise economy, including researches on economic, social and ecological impacts of cruise pollution (Miller et al., 2013; Murena et al., 2018), cruise energy efficiency (Lepistö et al., 2016), ecological cost (Carić, 2016), cruise's carbon emission (Howitt et al., 2010) and cruise ships' effects on public health and social costs, etc. (Chatzinikolaou et al., 2015; Mölders et al., 2013). Moreover, scholars also discuss the cruise ecological protection system and sustainable development mode in many ways. In spite of an increasing number of Chinese cruise 
references, fewer references concern impacts of cruise tourism, especially in regard to negative environment impacts of cruise economy, sustainable development and green treatment (Sun and Hou, 2017). Therefore, the academic study in China tends to "take foreign documents for references" and be led by policies. In the context of outdated cruise environment monitoring and a lack of relevant data, domestic scholars focus on the review and reference (Xie, et al., 2010; Qiu, 2007; Sun and Hou, 2017) of foreign documents which concern practical experience and researches on ecological pollution of foreign cruise ships and foreign ecological protection, such as shore power experience (Wu and Shen, 2012), green port construction (Ye et al., 2017), construction of a port ecological protection system (Ren, et al., 2017), etc. On the other hand, domestic scholars conduct researches on the measurement of carbon emission in cruise industry (Li and Lv, 2016), pollution prevention and control for cruise ships (Wang and Huang, 2015) and so on.

In view of all mentioned above, the academic world agrees that cruise tourism must follow the principle of sustainable development, and carbon emission and energy consumption of cruise ships must be strictly limited under the threshold (Yao and Chen, 2016). Tourism refers to an energy intensive industry (Becken, 2008). As an index giving consideration to both ecology and economy, ecological efficiency can indicate how to balance economic development and ecological impacts. The tourism ecological efficiency theory provides an access to bi-effect (Dobers and Wolff, 1999), that is, when job opportunities are created in the new market, costs and tourism's negative effects on the environment are reduced at the same time (Holleran, 2008). In a word, the essence of ecological efficiency is to create the maximum economic value with the minimum ecological impact. As the ecological efficiency analysis is a kind of typical quantitative analysis, it has been taken seriously and applied (Holleran and Lehto, 2008; Su, 2014; Gössling et al., 2005) by scholars in evaluation and quantitative analysis of tourism and sustainable development of cruise ships, including ecological efficiency research based on emission inventory ( $\mathrm{Su}, 2014)$ and research on ecological cost and ecological efficiency of cruise carbon footprint (Tichavska and Tovar, 2015). Though there are a great many Chinese and foreign researches on economic development and ecological pollution of cruise tourism at home and abroad, there are not sufficient ecological efficiency studies of how to balance economic development and ecological impacts of cruise tourism. The introduction of ecological efficiency to this paper helps analyze a balanced relationship between cruise tourism development and its ecological impact in a more profound way, discuss a coexistence mode of cruise economy and ecological environment, explore a harmonious and unified development mode for economy and ecology, seek for a way to promote ecological efficiency of cruise economy, and work out a cruise ecological pollution control system putting prevention first, paying attention to comprehensive treatment, and preventing and controlling pollution from the source.

\section{Research method and design}

\section{Evaluation method for ecological efficiency}

Evaluation methods of ecological efficiency mainly include the ratio method, index system method and model method (Yao and Chen, 2015; Peng et al., 2017). The ratio method makes sense by giving simple ratio values. The index system method, based on weight to express the relationship between environment and economy, may involve too much subjectivity. The model method mainly refers to the data envelopment analysis 
model, ecological topological method and so forth. In use of this kind of method, it is necessary to define weight of different indexes for integrating them to a single numerical value. In this case, the weight may lose objectivity. For studies into ecological efficiency, ecological risks and energy consumption caused by tourism become the focus at the present time. According to Gössling, ecological efficiency of tourism indicates a ratio between the carbon dioxide emission equivalent and tourism revenue (Gössling et al., 2005, 2007). In view of this, this paper applies the ratio method to compute ecological efficiency of cruise tourism in China.

When referring to the ratio method, a generally accepted ecological efficiency calculation formula is the calculation model proposed by World Business Council for Sustainable Development (WBCSD):

$$
E E=T R / C F T
$$

In this formula, EE stands for ecological efficiency, which can be described as the result that the revenue of cruise industry removes its ecological impacts. TR stands for the revenue of cruise industry, here uses the cruise tourism revenue to demonstrate, and CFT stands for the ecological impact of cruise industry, here uses its carbon footprint to present. All variable values shall be assigned to the increment of a product or service or ecological impacts according to the nature of industry. The total amount of carbon footprint from cruise travel is selected as the index of ecological impacts of cruise tourism, while cruise tourism revenue is selected as the index to measure economic value of tourism.

\section{Calculation formula for cruise carbon footprint and coefficient determination}

\section{a. Calculation of total carbon footprint from cruise travel}

Caron footprint originates from the concept of "ecological footprint", refers to the land needed to absorb the carbon emission. But with the development of the carbon footprint theory, now it has almost been expressed as carbon dioxide equivalent. In this paper, carbon footprint from cruise travel is decided by the carbon emission from fuel consumption, solid waste and sewage discharge of cruise ships. The designed formula is as follows:

$$
G C F=\sum_{i} G_{i} * C E_{i}
$$

In Equation 2, GCF stands for total carbon footprint from cruise ships, "i" stands for energy and different types of waste and they are marine fuel oil, solid waste and sewage, G stands for amount of energy consumption or generated waste, and CE stands for response carbon emission coefficient.

\section{b. Calculation of carbon emission of cruise fuel oil}

In this paper, Wang (2015) is mainly used to calculate the carbon emissions of cruise ships. At the same time, according to the trend of large-scale cruise ships and the extension of berthing time in recent years, the specific values of the correlation coefficient are improved to make the calculation more scientific and reasonable. Based on the theme of low-carbon green development of Shanghai cruise port, Wang Bowen used this model to quantitatively and intuitively calculate specific carbon dioxide 
emission data, quantitatively analyze the carbon emissions of cruise port, and provide guidance for the development of low-carbon green operation of cruise port. In addition, $\mathrm{Li}$ and $\mathrm{Lu}$ (2016) used the bottom-up dynamic method to calculate the emission of sulfur oxides and particulates from cruise ships, and the principle of the dynamic method is similar to the formula used in this paper.

The topic of this paper lies in carbon emission from cruise travel in China and thus the carbon footprint defined in this paper must be within Chinese territory. The main focus is carbon emission of cruise fuel oil consumed during the period from the moment when a cruise enters the sea of China to its docking to the moment when a cruise leaves the port to arrival of an open sea, namely, the carbon footprint during cruise ships' berthing. This paper believes carbon footprint during cruise ships' berthing is mainly related to the number of cruise ships moored to the port (see Table 1), the duration of berthing, etc. The calculation thought is to transfer the electrical load during cruise berthing to the amount of fuel consumed during berthing via engine fuel efficiency; and then calculate carbon footprint by using the carbon emission coefficient of fuel oil. The correlation values in the formula (e.g. $W=10.5$ megawatt, $Y=200 \mathrm{~g} / \mathrm{kWh}$ ) are borrowed from the data in previous studies (Dong, 2017; Yang, 2013; Gui et al., 2017). The calculation formula for $\mathrm{CO}_{2}$ pollutants generated from cruise ship is:

$$
S=N \cdot W \cdot t \cdot Y \cdot \beta \cdot \eta
$$

$S$ is the total amount of $\mathrm{CO}_{2}$ emission; $N$ is the number of cruise ships moored to the port annually; $N$ is electrical load for berthing, and $\mathrm{W}=10.5$ megawatt; $t$ is the duration of cruise berthing, and $\mathrm{t}=11.95 \mathrm{~h}$ (average value); $Y$ is power consumed by diesel engine, and fuel consumption power of oil engine on the cruise is $200 \mathrm{~g} / \mathrm{kWh} ; \beta$ is the combustion carbon emission coefficient; HFO carbon emission factor is $3.114 \mathrm{~kg}$ $\mathrm{CO}_{2} / \mathrm{KG} ; \eta$ is the electrical grid power factor of cruise and $\eta=7.5$.

Table 1. Recommended discharge coefficient of cruise solid wastes. (Source: IPCC2006, General Principles for Calculation of the Comprehensive Energy Consumption (GBT 25892008))

\begin{tabular}{c|c|c|c|c|c|c}
\hline \multirow{4}{*}{$\begin{array}{c}\text { Fuel } \\
\text { type }\end{array}$} & \multicolumn{2}{|c|}{$\mathbf{A}$} & \multicolumn{2}{c|}{$\mathbf{B}$} & \multicolumn{2}{c}{$\mathbf{C = A \times \mathbf { B }}$} \\
\cline { 2 - 7 } & $\begin{array}{c}\mathbf{C O}_{2} \text { emission original coefficient } \\
\text { from IPCC2006 }\end{array}$ & \multicolumn{2}{c|}{ Heating value of China } & \multicolumn{2}{c}{$\begin{array}{c}\text { Recommended emission } \\
\text { coefficient }\end{array}$} \\
\cline { 2 - 7 } & Original coefficient & Unit & $\begin{array}{c}\text { Heating } \\
\text { value }\end{array}$ & $\begin{array}{c}\text { Unit of } \\
\text { heating value }\end{array}$ & $\begin{array}{c}\text { Numerical } \\
\text { value }\end{array}$ & Unit \\
\hline $\begin{array}{c}\text { Solid } \\
\text { waste }\end{array}$ & $3.84 \mathrm{E}-04$ & $\mathrm{Kg} \mathrm{CO}_{2} / \mathrm{Kcal}$ & 2,955 & $\mathrm{kcal} / \mathrm{kg}$ & 1.13 & $\mathrm{KgCO}_{2} / \mathrm{kg}$ \\
\hline
\end{tabular}

The carbon emission coefficient of cruise fuel oil in this paper is in accordance with relevant Chinese regulations on marine fuel oil. In Notice on Issuing the Implementation Plan for the Marine Air Pollutant Emission Control Area, issued by Ministry of Transport of the People's Republic of China in 2018, it is specified that sea ships should consume marine fuel oil whose Sulphur content does not exceed $0.5 \% \mathrm{~m} / \mathrm{m}$ since January 1, 2019 when they enter the emission control area. This means cruise ships consumed heavy oil before 2019. In this paper, the carbon emission coefficient of HFO and $\mathrm{MGO}$ are $3.114 \mathrm{kgCO}_{2} / \mathrm{kg}$ and $3.205 \mathrm{kgCO}_{2} / \mathrm{kg}$, respectively. 


\section{c. Calculation of carbon footprint from solid waste of cruise ships}

This paper borrows carbon emission original coefficients of different emission sources and different fuels from IPCC2006. The carbon emission original coefficient multiplied by the heating value equals to the recommended carbon emission coefficient of this type of fuel in China. For the heating value of solid waste, see the heating value of municipal solid waste, as shown in Table 1.

\section{d. Calculation of carbon footprint of cruise solid waste}

There is a lack of exact data about sewage carbon discharge domestically. For this reason, the sewage carbon discharge in this paper is replaced by the indirect carbon discharge of power consumption and use of PAM during sewage treatment. Power consumption and PAM consumption are two major indirect discharge sources from the sewage treatment plant. The carbon emission coefficient of power consumption varies greatly from 0.6 to $1.2 \mathrm{kgCO}_{2} /(\mathrm{kWh})$ with types of fuels used for local electricity generation. This paper cites the data of power supply emission intensity based on the national carbon market base value in 2015: $0.8066 \mathrm{kgCO}_{2} / \mathrm{kWh}$. As the discharge coefficient of carbon consumed by PAM ranges from 20 to $30 \mathrm{kgCO}_{2} / \mathrm{kg}$, this paper adopts the average value of $25 \mathrm{kgCO}_{2} / \mathrm{kg}$. The statistical data in 2010 shows sewage per cubic meter consumes $0.24 \mathrm{~kW}$ electricity and $0.00076 \mathrm{~kg}$ PAM. The sewage carbon discharge coefficient formula in this paper is:

$$
C E_{P W}=E_{P W} * C E_{E}+P A M_{P W} * C E_{P A W}
$$

In Equation 4, PWCE stands for the sewage carbon discharge coefficient, Epw stands for electricity consumption for sewage treatment, CEE stands for power carbon discharge coefficient; PAMpw stands for the amount of PAM used for sewage treatment, and CEPAM stands for the carbon discharge coefficient of PAM. Upon calculation, the sewage carbon discharge coefficient is $0.212584 \mathrm{kgCO}_{2} / \mathrm{m}^{3}$.

\section{e. Discussion of uncertainty of the discharge coefficient}

The carbon discharge original coefficient of energy in this paper are quoted from IPCC2006. For the combustion heating values of energy and waste, refer to national standard General Principles for Calculation of the Comprehensive Energy Consumption (GBT 2589-2008) released in 2008; average carbon emission per kilowatt hour in China $(\mathrm{kg} / \mathrm{kWh})$ is selected as the power carbon discharge coefficient used in the sewage carbon discharge calculation formula. Therefore, the coefficient uncertainty in this paper mainly comes from the regional differences domestically and there is a deviation from the actual carbon discharge coefficient.

\section{Data collection}

This paper collects data mainly from Annual Report on China's Cruise Industry (2016), Annual Report on China's Cruise Industry (2017), Annual Report on China's Cruise Industry (2018) and other relevant materials. Relevant coefficient values involved in carbon discharge calculation and the quantity of pollutants from tourists per day come from related studies as mentioned above. The quantity of pollutants per tourist is: $4 \mathrm{~kg}$ solid waste; $40 \mathrm{~L}$ black water; $340 \mathrm{~L}$ gray water; $10 \mathrm{~L}$ bilgy oily water; 
$0.16 \mathrm{~kg}$ toxic waste. The data on annual revenue in cruise tourism market from 2009 to 2017 comes from Annual Report on China's Cruise Industry (CCYIA, 2016), and the data on annul tourist reception in China cruise tourism industry and the data on the annual number of received cruise ships from 2009 to 2017 come from Annual Report on China's Cruise Industry (Wang, Ye, 2018), as shown in Table 2. The average value of cruise berthing durations in 2015, 2016 and 2017 is taken as the berthing duration.

Table 2. Total number of cruise ships received by China, scale of the cruise tourism market and trading volume from 2009 to 2017. (Data source: Annual Report on China's Cruise Industry (2018), CCYIA)

\begin{tabular}{c|c|c|c|c|c|c|c|c|c}
\hline Year & $\mathbf{2 0 0 9}$ & $\mathbf{2 0 1 0}$ & $\mathbf{2 0 1 1}$ & $\mathbf{2 0 1 2}$ & $\mathbf{2 0 1 3}$ & $\mathbf{2 0 1 4}$ & $\mathbf{2 0 1 5}$ & $\mathbf{2 0 1 6}$ & $\mathbf{2 0 1 7}$ \\
\hline $\begin{array}{c}\text { Cruise ships } \\
\text { received by China } \\
\text { (total number) }\end{array}$ & 259 & 294 & 272 & 275 & 406 & 466 & 629 & 1,010 & 1,181 \\
\hline $\begin{array}{c}\text { Trading volume of } \\
\text { the cruise tourism } \\
\text { market (100 million } \\
\text { yuan) }\end{array}$ & 19.7 & 23.8 & 7.1 & 11.8 & 26.2 & 33.5 & 45.3 & 60.8 & 82.3 \\
\hline $\begin{array}{c}\text { Number of received } \\
\text { cruise tourists (unit: } \\
10,000 \text { persons) }\end{array}$ & 34.38 & 48.08 & 47.85 & 65.69 & 120.15 & 172.37 & 248 & 456.66 & 495.42 \\
\hline
\end{tabular}

\section{Research process and result analysis}

\section{Time evolution and characteristics of cruise carbon footprint}

According to the data in Table 2, the carbon footprint of cruise ships received by China from 2009 to 2017 it obtained from Equations 1 and 2. Table 3 shows values of annual and total carbon footprint of fuel oil, sewage and solid waste released by Chinese cruise ships from 2009 to 2017. Among three types of carbon footprint, solid waste, which is the most important source of carbon footprint, produces the largest carbon footprint load; fuel oil plays a secondary role, and carbon footprint from sewage occupies the smallest part.

Table 3. Carbon footprints generated by cruise ships received in China from 2009 to 2017

\begin{tabular}{c|c|c|c|c|c|c|c|c|c}
\hline $\begin{array}{c}\text { Carbon } \\
\text { emission }\end{array}$ & $\mathbf{2 0 0 9}$ & $\mathbf{2 0 1 0}$ & $\mathbf{2 0 1 1}$ & $\mathbf{2 0 1 2}$ & $\mathbf{2 0 1 3}$ & $\mathbf{2 0 1 4}$ & $\mathbf{2 0 1 5}$ & $\mathbf{2 0 1 6}$ & $\mathbf{2 0 1 7}$ \\
\hline $\begin{array}{c}\text { Cruise } \\
\text { fuel oil }\end{array}$ & 1516.03 & 1723.12 & 1594.17 & 1611.76 & 2379.54 & 2731.2 & 3686.53 & 5919.55 & 6921.77 \\
\hline $\begin{array}{c}\text { Cruise } \\
\text { sewage }\end{array}$ & 7.04 & 9.84 & 9.80 & 13.43 & 24.60 & 35.3 & 50.78 & 93.5 & 101.4 \\
\hline $\begin{array}{c}\text { Solid } \\
\text { waste }\end{array}$ & 404.03 & 565.04 & 562.33 & 771.99 & 1412 & 2025.69 & 2914.5 & 5366.67 & 5822.18 \\
\hline $\begin{array}{c}\text { Total } \\
\text { amount }\end{array}$ & 1927.11 & 2298 & 2166.31 & 2379.20 & 3816.14 & 4792.18 & 6651.8 & 11379.72 & 12845.38 \\
\hline
\end{tabular}

Table 3 lists carbon footprints from different sources and total amount of carbon emission. On this basis, this paper analyzes carbon emission composition and growth 
change of China cruise tourism from 2009 to 2017, finds that cruise carbon emission shows a growing momentum when the number of cruise ships berthing in China increases (Fig. 1). The carbon emission from the fuel oil contributes the largest part to total emission. In respect to the growth rate of cruise carbon emission, the rate of fuel emission, solid waste carbon emission and overall carbon emission fluctuates greatly, and the fluctuation trend is similar.

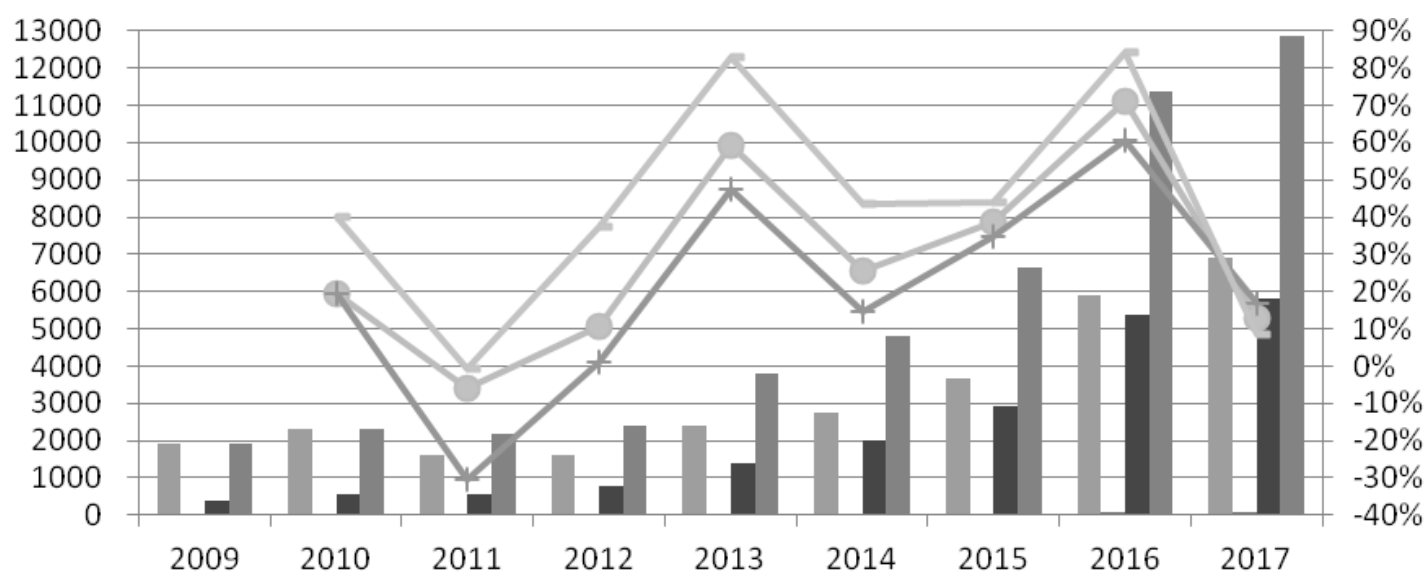

Carton emission of cruise fuel oil $(10000 \mathrm{~kg})$

Carton emission of sewage $(10000 \mathrm{~kg})$

Carton emission of solid waste $(10000 \mathrm{~kg})$

Total carton emission $(10000 \mathrm{~kg})$

- Total growth rate

$\ldots$ Growth rate ofcruise fuel oil

Growth rate of solid waste

Figure 1. Carbon footprints composition and growth change of China cruise tourism from 2009 to 2017

\section{Calculation of ecological efficiency of China cruise tourism}

Table 4 shows the values of China's annual cruise revenue, total cruise carbon emission and ecological efficiency of cruise tourism from 2009 to 2017. These values are got by calculation according to the ratio of annual cruise travel revenue and total cruise carbon emission annually in Equation 1.

Table 4. Ecological efficiency of China cruise tourism from 2009 to 2017

\begin{tabular}{c|c|c|c|c|c|c|c|c|c}
\hline & $\mathbf{2 0 0 9}$ & $\mathbf{2 0 1 0}$ & $\mathbf{2 0 1 1}$ & $\mathbf{2 0 1 2}$ & $\mathbf{2 0 1 3}$ & $\mathbf{2 0 1 4}$ & $\mathbf{2 0 1 5}$ & $\mathbf{2 0 1 6}$ & $\mathbf{2 0 1 7}$ \\
\hline $\begin{array}{c}\text { Total carbon } \\
\text { emission of cruise } \\
\text { ships (10000 kg) }\end{array}$ & 1927.11 & 2298.00 & 2166.31 & 2397.20 & 3816.14 & 4792.18 & 6651.80 & 11379.72 & 12845.38 \\
\hline $\begin{array}{c}\text { Tourist revenue of } \\
\text { cruise ships } \\
(10000 \text { yuan) }\end{array}$ & 197000 & 238000 & 71000 & 118000 & 262000 & 335000 & 453000 & 608000 & 823000 \\
\hline $\begin{array}{c}\text { Ecological efficiency } \\
\text { of cruise tourism }\end{array}$ & 102.23 & 103.57 & 32.77 & 49.22 & 68.66 & 69.91 & 68.10 & 53.43 & 64.07 \\
\hline
\end{tabular}

Figure 2 mainly reflects the ecological efficiency tendency of China cruise tourism over time from 2009 to 2017 and its average level. In these nine years, ecological 
efficiency of China cruise tourism has generally declined, its numerical value is still low and the average value is merely CNY 67.99/kg. Hence, ecological efficiency of China cruise tourism needs to be improved essentially. In 2011, China's cruise tourist ecological efficiency was at a record low of CNY $32.77 / \mathrm{kg}$. This is because Chinese tourist revenue in 2011 fell as historically low as CNY 710 million but cruise carbon emission of cruise ships did not decrease. From 2009 to 2017, the maximum value of cruise tourist ecological efficiency in China is CNY 103.57/kg.

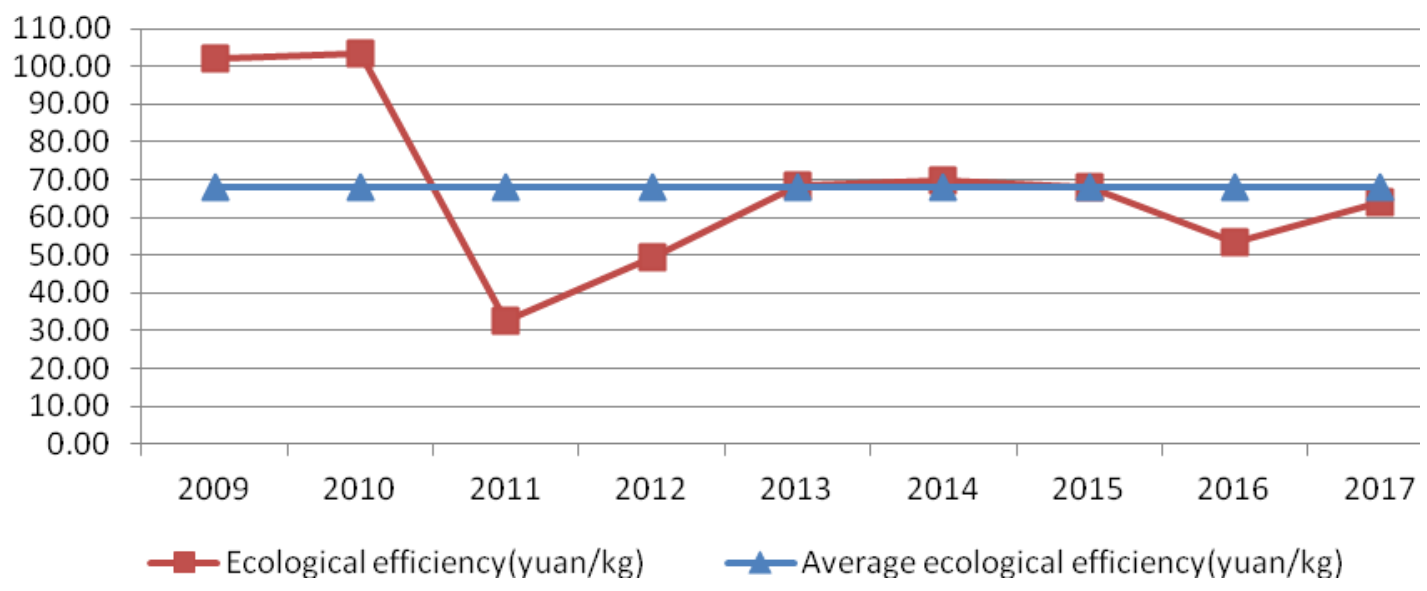

Figure 2. Time evolution of China's cruise tourist ecological efficiency from 2009 to 2017

\section{Result analysis}

Analysis on the time evolution characteristics of China cruise tourist ecological efficiency from 2009 to 2017

According to Figure 2, ecological efficiency of China cruise tourism shows an overall downtrend momentum from 2009 to 2017. The average tourist ecological efficiency is CNY 67.99/kg, namely, $1 \mathrm{~kg}$ pollutants are generated as soon as China cruise tourism earns CNY 67.99. In these nine years, the values of cruise tourist ecological efficiency from 2011 to 2012 and from 2016 to 2017 are lower than the average value and the values from 2009 to 2010 are higher than the average value and the values from 2015 to 2015 and 2017 are close to the average value. In 2011, China's cruise tourist ecological efficiency was at a record low of CNY $32.77 / \mathrm{kg}$. This is because Chinese tourist revenue in 2011 fell as historically low as CNY 710 million, but cruise carbon emission of cruise ships did not decrease. In 2009-2017, cruise tourist ecological efficiency in China reached a record high of CNY 103.57/kg.

The overall ecological efficiency of China cruise tourism, which is still relatively low, does not benefit much from the continuously expansion of China's cruise tourist market. There are two root causes. The first one lies in low contribution of China cruise tourism to economy. International cruise lines play a leading role in global cruise industry and thus most economic benefit of cruise industry drains away. In this case, China benefits a little from the international cruise tourism. The second reason is a waste of resources and tourist spending. This is because China is still in the early stage of development to attract investment and expand size when the cruise market is moving eastward and the numbers of cruise tourists, cruise ships received in Chinese ports are growing; most cruise ships are used for outbound travel, featuring high mobility and 
hidden environment pollution; due to a lack of relevant legal norms and backward maritime control, ecological problems caused by cruise travel have not been taken seriously and treated, and the ecological cost of cruise economy for development has not been taken into account.

\section{Carbon footprint change of cruise tourism in China from 2009 to 2017}

With the rapid development of China cruise tourism, the ever-growing numbers of cruise ships and cruise tourists lead to constant growth of cruise fuel consumption, solid waste, sewage discharge and tourist food consumption etc. In view of this, the total carbon footprint of cruise ships also rises. According to Figure 1 and Table 2, carbon footprint of cruise solid waste shows a fast-growing momentum with the tourist development in China and this momentum becomes more obvious especially from 2011 to 2013. Furthermore, among the total carbon footprint of cruise ships, cruise fuel oils accounts for the largest proportion.

\section{Conclusions and suggestions}

On the basis of analysis above, the following points can be concluded: firstly, ecological efficiency of China's cruise tourism is still low and generally show a downward trend from 2009 to 2017 and the value of average ecological efficiency is merely CNY 67.99/kg. There's a lot of room for improvement. Secondly, accompanied by vigorous growth of tourists' reception and cruise ships' visits, cruise ships' impact on the environment from 2009 to 2017 becomes more serious. In particular, carbon emission of solid waste occupies the largest proportion and exerts the greatest impact on environment.

Owing to rapid expansion of China cruise tourism, the numbers of cruise ships berthing in ports and tourists are increasing quickly. Accordingly, resource occupancy and consumption, waste discharge and pollution brought by industrial expansion also become serious. All of this is challenging the sustainable development of areas around ports and sea areas. As a result, importance must be attached to ecological problems caused by cruise tourism and seek solutions. Firstly, it is suggested to re-examine China's cruise tourism development structure and industrial layout, promote the continuous upgrading and transformation of the cruise industry towards low-carbon, high efficiency and ecological protection, and build an ecologically-efficient cruise economic development model. Secondly, it is suggested to raise tourists' and the public's concerns over cruise lines, green ecology of ports and enterprises' ecological behaviors, and encourage tourists to convert consumption concept and use green products. In this way, it is available to reduce tourism consumption waste, control uncivilized ecological behaviors, and form a responsible consumption pattern of green tourism. Thirdly, it is suggested to promote intelligent transformation of cruise economy with the help of new technological revolution, and advocate construction of smart cruise, smart port and smart tourism; on the other hand, it is suggested to propel the use of shore power at ports, clean energy cruise ships, air filtration and sewage treatment to build a market-oriented green technology innovation system; finally, the national government and departments concerned should formulate specific and detailed legal rules of cruise travel to restrict behaviors of cruise passengers, cruise lines, cruise ships and support the green development of China cruise ships. 
In future, China should explore actively the institutional assurance and operation mechanism. The first step is to make and perfect energy, ecological protection, economy, ocean, science and technology policies which can drive the green development of cruise ships, increase fiscal subsidies and policy support for clean energy, shore power technologies, energy conservation and ecological protection technologies, and perfect systems for coastal and marine ecological management and ecological management to build a policy system and a guidance mechanism for advocating clean production, low carbon emission and green development of cruise industry; the second step is to bring into full play the synergistic effect among climate change, energy conservation and ecological protection, new energy development, and ecological improvement, seek a stable and sustainable long-term capital investment operation mechanism, an efficient mechanism for transferring international low carbon ecological protection technologies and a public information platform to provide public mechanism guarantee for green development in terms of capital and technological information; the third step is to improve functions of maritime and coast guard departments for regulating marine ecosystem, clarify the supervision subject and personnel agency for coping with ecological environment problems caused by cruise ships, solidify cruise waste discharge and the sea area regulatory process, coordinate with relevant departments to take joint actions, and provide institutional safeguards for green regulators.

Acknowledgements. We are very grateful to express our special thanks to the grant of the National Social Science Foundation to the project study "Research on the development of domestic cruise tourism in China under the adjustment of supply structure" (No. 16BGL110), and the Ministry of Education to the youth planning project study "Research on the Environmental Externality and Green Governance Path of China's Cruise Industry from the Perspective of Ecological Economy" (No. 19YJC790117).

\section{REFERENCES}

[1] Becken, S. (2008): Developing indicators for managing tourism in the face of peak oil. Tourism Management 29(4): 695-705.

[2] Carić, H. (2016): Challenges and prospects of valuation - cruise ship pollution case. Journal of Cleaner Production 111: 487-498.

[3] Chang, Y. T., Park, H., Liu, S. M., et al. (2016): Economic impact of cruise industry using regional input-output analysis: a case study of Incheon. - Maritime Policy \& Management 43(1): 1-18.

[4] Chase, G. L., Mckee, D. L. (2003): The economic impact of cruise tourism on Jamaica. Journal of Tourism Studies 14(2): 16-22.

[5] Chatzinikolaou, S. D., Oikonomou, S. D., Ventikos, N. P. (2015): Health externalities of ship air pollution at port - Piraeus Port case study. - Transportation Research Part D Transport \& Environment 40: 155-165.

[6] China Cruise \& Yacht Industry Association, Hongkou District People's Government of Shanghai (2016): Annual Report on China's Cruise Industry (2015). - Shanghai International Shipping Institute, Shanghai.

[7] Dobers, P., Wolff, R. (1999): Eco-efficiency and dematerialization: scenarios for new industrial logics in recycling industries, automobile and household appliances. - Business Strategy \& the Environment 8(1): 31-45.

[8] Dong, L. (2017): High-voltage shore power connection system and application of luxury cruise terminals. - Jiangsu Ship 34(2): 24-27. 
[9] Erize, F. J. (1987): The impact of tourism on the Antarctic environment. - Environment International 13(1): 133-136.

[10] Gibson, P., Walters, C., Vogel, M., et al. (2012): Human Resource Management in the Cruise Industry. - In: Vogel, M. et al. (eds.) The Business and Management of Ocean Cruises. CABI, Wallingfrod, pp. 101-103.

[11] Gössling, S., Peeters, P., Ceron, J. P., et al. (2005): The eco-efficiency of tourism. Ecological Economics 54(4): 417-434.

[12] Gössling, S., Broderick, J., Upham, P., et al. (2007): Voluntary carbon offsetting schemes for aviation: efficiency, credibility and sustainable tourism. - Journal of Sustainable Tourism 15(3): 223-248.

[13] Gui, S., Guo, Y., Gao, S., et al. (2017): Load analysis of power system of cruises in port. - Journal of Shanghai Maritime University 38(2): 61-65.

[14] Holleran, J. N. (2008): Sustainability in tourism destinations: exploring the boundaries of eco-efficiency and green communications. - Journal of Hospitality \& Leisure Marketing 17(3-4): 373-394.

[15] Holleran, J. N., Lehto, X. Y. (2008): Sustainability in tourism destinations: exploring the boundaries of eco-efficiency and green communications. - Journal of Hospitality \& Leisure Marketing 17(3-4): 373-394.

[16] Howitt, O. A., Revol, V. N., Smith, I. J., et al. (2010): Carbon emissions from international cruise ship passengers' travel to and from New Zealand. - Energy Policy 38(5): 2552-2560.

[17] Johnson, D. (2002): Environmentally sustainable cruise tourism: a reality check. - Marine Policy 26(4): 261-270.

[18] Jones, R. J. (2007) Chemical contamination of a coral reef by the grounding of a cruise ship in Bermuda. - Marine Pollution Bulletin 54(7): 905-911.

[19] Jones, R. J. (2011): Environmental effects of the cruise tourism boom: sediment resuspension from cruise ships and the possible effects of increased turbidity and sediment deposition on Corals (Bermuda). - Bulletin of Marine Science 87(3): 659.

[20] Lepistö, V., Lappalainen, J., Sillanpää, K., et al. (2016): Dynamic process simulation promotes energy efficient ship design. - Ocean Engineering 111: 43-55.

[21] Li, H., Lv, S. (2016): Environmental pollution measurement and control situation analysis of cruise travel - taking Shanghai Port as an example. - Ocean Development and Management 12: 32-38.

[22] Lincoln, C. L., Krause, C. B., George, K., et al. (2006): The significance of dilution in evaluating possible impacts of wastewater discharges from large cruise ships. - Marine Pollution Bulletin 52(6): 681-688.

[23] Miller, F. P., Vandome, A. F., Mcbrewster, J. (2013): Cruise ship pollution. - Alphascript Publishing.

[24] Mölders, N., Gende, S., Pirhalla, M. (2013): Assessment of cruise ship activity influences on emissions, air quality, and visibility in Glacier Bay National Park. - Atmospheric Pollution Research 4(4): 435-445.

[25] Murena, F., Mocerino, L., Quaranta, F., et al. (2018): Impact on air quality of cruise ship emissions in Naples, Italy. - Atmospheric Environment 187: 70-83.

[26] Peng, H., Zhang, J., Han, Y., et al. (2017): SBM-DEA model and empirical analysis of ecological efficiency measurement of tourism destinations. - Acta Ecologica Sinica 37(2): 628-638.

[27] Qiu, C. (2007): Anti-pollution thinking triggered by cruise economy boom. - Research on Waterborne Transportation 3: 54-56.

[28] Ren, C., Sun, R., Ye, X. (2017): Research prospect of environmental protection of cruise ports. - Journal of Shanghai University of Engineering Science 31(2): 166-173.

[29] Ritter, W., Schafer, C. (1998): Cruise-tourism. - Tourism Recreation Research 23(1): 6571. 
[30] Su, S. (2014): Ship emissions inventory, social cost and eco-efficiency in Shanghai Yangshan Port. - Atmospheric Environment 82(1): 288-297.

[31] Sun, X., Hou, Y. (2017): Summary of research on negative effect and responsibility of cruise travel. - Progress in Geography 36(5): 569-584.

[32] Tichavska, M., Tovar, B. (2015): Environmental cost and eco-efficiency from vessel emissions in Las Palmas Port,. -Transportation Research Part, E. 83(3): 126-140.

[33] Vina, L. L., Ford, J. (1999): Economic impact of proposed cruise ship business. - Annals of Tourism Research 26(1): 0-207.

[34] Wang, H., Ye, X. (2018): Annual Report on China's Cruise Industry (2018). - Social Sciences Academic Press, Beijing.

[35] Wang, J., Huang, J. (2015): Pollution prevention and control of cruise tourism at home and abroad under the model of circular economy and its Hainan enlightenment. - Journal of Green Science and Technology 10: 296-299.

[36] Wu, G., Shen, Y. (2012): Shore power design concept for large cruise terminals. - Port \& Waterway Engineering 5: 74-76.

[37] Xie, F., Li, H., Li, D. (2010): Environmental pollution control mechanism of cruise based on full life cycle assessment and its countermeasures. - Marine Science Bulletin 6: 702706.

[38] Yang, R. (2013): Research and standard construction on the technology of receiving shore power by cruises in port. - Port Engineering Technology 5: 30-34.

[39] Yao, Z., Chen, T. (2015): Tourism ecological efficiency model and its empirical study. Chinese Journal of Population Resources and Environment 25(11): 113-120.

[40] Yao, Z., Chen, T. (2016): Research progress in tourist ecological efficiency. - Tourism Science 30(6): 74-91.

[41] Ye, X., Sun, R., Liu, M. (2017): Development situation of Green Cruise Port and its breakout path. - China Ship Survey 7: 60-63. 